19 Shaper, A G, et al, fournal of Atherosclerosis Research, 1966, 6, 313.

${ }^{20}$ Grace, C S, Australian Annals of Medicine, 1969, 18, 32.

21 Grace, C S, and Goldrick, R B, Fournal of Atherosclerosis Research, 1968, 8, 705 .

${ }^{22}$ Grace, C S, Clinical Science, 1968, 34, 497.

${ }^{23}$ Bennett, N B, et al, fournal of Clinical Pathology, 1966, 19, 241.

24 Warlow, C P, et al, fournal of Clinical Pathology, 1972, 25, 484.

${ }^{25}$ Korsan-Bengsten, K, et al, Thrombosis Research, 1972, 1, 389.

${ }^{26}$ Billimoria, J D, et al, Atherosclerosis, 1975, 21, 61.

27 Janzon, L, and Nillson, I M, Circulation, 1975, 51, 1120.

28 Meade, T W, et al, British Heart fournal, 1978, 40, 789.

29 Castelli, W P, et al, Lancet, 1977, 2, 153.

30 Barboriak, J J, et al, British Heart fournal, 1977, 39, 289.
31 Yano, K, Rhoads, G G, and Kagan, A, New England fournal of Medicine, 1977, 297, 405.

${ }^{32}$ Fearnley, G R, et al, Lancet, 1960, 1, 184

33 Shaper, A G, et al, British Medical fournal, 1975, 3, 571.

${ }^{34}$ Meade, T W, et al, British fournal of Haematology, 1976, 34, 351.

${ }^{35}$ Mann, J I, et al, British fournal of Preventive Medicine, 1976, 30, 94.

${ }^{36}$ Office of Population Censuses and Surveys, Occupational Mortality 1970 1972. London, HMSO, 1978.

${ }^{37}$ Meade, T W, Chakrabarti, R, and North, W R S, in Atherosclerosis, Metabolic, Morphologic and Clinical Aspects, ed G W Manning and M D Haust. New York, Plenum, 1977.

\title{
Comparative study of automatic blood-gas analysers and their use in analysing arterial and capillary samples
}

\author{
P RUBIN, S BRADBURY, K PROWSE
}

British Medical fournal, 1979, 1, 156-158

\section{Summary and conclusions}

Three automatic blood-gas analysers were compared for ease of use; calibration; reproducibility and accuracy of results; maintenance; fault-finding; and use of expert technician time. Results obtained from arterial and capillary blood were compared with duplicate values obtained with a semi-automatic analyser controlled and calibrated with tonometered blood. No analyser was fully automatic, and all three needed maintenance by expert technicians. Difficulties were encountered when inexperienced operators used the machines. One automatic blood-gas analyser gave aberrant values for oxygen pressure $\left(\mathrm{Po}_{2}\right)$ due to electrode dysfunction that was not indicated by the fault-finding system. A second analyser gave significantly lower values for blood pH than the standard machine. A comparison of $\mathrm{pH}$, carbon dioxide pressure $\left(\mathrm{PCO}_{2}\right)$, and $\mathrm{Po}_{2}$ measured in 40 simultaneous paired samples of arterial and arterialised capillary blood showed no significant difference for $\mathbf{p H}$ or $\mathrm{PCO}_{2}$, but the $\mathrm{Po}_{2}$ values were significantly lower in the capillary samples over the range studied.

We conclude that all machines perform satisfactorily in terms of blood-gas analysis, but none may be regarded as fully automatic. Some degree of technical supervision is essential, as is proper training for all potential users.

\section{Introduction}

The importance of blood-gas measurements in intensive-care medicine and paediatrics has led to the introduction of blood-gas analysers with automatic facilities. The advantage of such

North Staffordshire Hospital Centre, City General Hospital, Stoke on Trent ST4 6QG

P RUBIN, BM, MRCP, medical registrar (present appointment: research fellow, division of clinical pharmacology, Stanford University, California USA)

S BRADBURY, chief technician, department of respiratory physiology K PROWSE, MD, MRCP, consultant physician machines is that they may be sited outside the routine laboratory, close to an acute unit where frequent measurements are required, and their automatic facilities enable measurements to be made by non-laboratory staff such as doctors and senior nurses.

We report a study of three currently available automatic blood-gas analysers and compare results obtained from arterial and arterialised capillary samples.

\section{Methods}

We studied one model of each of three automatic blood-gas analysers-namely, the Corning 175 (Corning Medical); the IL 613 (Instrumentation Laboratory (UK) Limited); and the Radiometer ABL2 (Radiometer, Copenhagen). The machines were studied consecutively. We chose these three models because they were the three automatic blood-gas analysers available in this country. The machines tested were demonstration models four to six months old, which were supplied and set up in the laboratory by the manufacturers. The machines were studied for one week each, during which they were used by technicians experienced in blood-gas analysis, who tested them for stability, ease of calibration and maintenance, reproducibility of results, fault-finding, and general usage. During a subsequent two-day period they were tested by medical and nursing staff with no experience of blood-gas analysis.

Duplicate measurements of $\mathrm{pH}$, carbon dioxide pressure $\left(\mathrm{PCO}_{2}\right)$ and oxygen pressure $\left(\mathrm{PO}_{2}\right)$ were made in arterial blood and arterialised capillary blood samples taken from patients in the respiratory unit. Arterial samples were taken by percutaneous brachial artery puncture, $2 \mathrm{ml}$ of arterial blood being drawn into a heparinised plastic syringe. The samples were immediately placed in ice and the measurements made within five minutes. Arterialised capillary samples were taken by the method of Godfrey $e t a l^{1}$ and were also analysed within five minutes. The order of analysis of arterial and capillary samples was randomised. The results obtained with the three machines were compared with duplicate values obtained from the same samples with a semi-automatic machine (Corning 165), which was used by an experienced technician. The Corning 165 was calibrated daily using both standard buffer and gases (BDH: $\mathrm{pH} 6.840 \pm 0.005$ at $37^{\circ} \mathrm{C}$ and $\mathrm{pH} 7.380 \pm 0.005$ at $37^{\circ} \mathrm{C}$ ) and tonometered blood (IL 237 tonometer). ${ }^{2}$ The machine is accurate within about $3 \%{ }^{3}$

In a further study we compared measurements obtained with each machine with those obtained from 40 duplicate arterial and capillary samples with the Corning 165.

Statistical methods-To compare values obtained with the individual machines and the Corning 165 and from arterial and capillary samples we used the overall test based on the null hypothesis described by Silvey. ${ }^{4}$ Mean values were compared by the paired $t$ test and standard deviations by the variance-ratio $(F)$ test. 


\section{Results}

COMPARISON OF AUTOMATIC ANALYSERS

\section{Calibration}

Calibration is automatic on both the ABL2 and the Corning 175. The IL 613 required manual calibration each morning, and whenever two-point calibration checks were necessary. The daily checks were similar for all three analysers. Table I shows the frequency of calibration.

\section{Maintenance}

Weekly and monthly maintenance was minimal on all three machines and entailed membrane checks and changing the potassium hydroxide solution. Membrane changes were easy on the $\mathrm{O}_{2}$ and $\mathrm{CO}_{2}$ electrodes

TABLE I-Details of calibration, speed with which results produced, and warm-up time after shut-down for each machine

\begin{tabular}{|c|c|c|c|}
\hline & ABL2 & Corning 175 & IL 613 \\
\hline $\begin{array}{l}\text { Frequency of calibration: } \\
\text { Two-point } \\
\text { One-point }\end{array}$ & 2-hourly & $\begin{array}{l}\text { 2-hourly } \\
\text { 1-hourly }\end{array}$ & $\begin{array}{l}\text { Manual } \\
\text { After each sample } \\
\text { and every } 20 \mathrm{~min}\end{array}$ \\
\hline $\begin{array}{l}\text { Speed of automatic calibration } \\
\text { Speed of results } \\
\text { Warm-up time after shut-down }\end{array}$ & $\begin{array}{l}6 \mathrm{~min} \\
150 \mathrm{~s} \\
4 \mathrm{~h}\end{array}$ & $\begin{array}{l}4 \mathrm{~min} \\
90 \mathrm{~s} \\
2 \mathrm{~h}\end{array}$ & $\begin{array}{l}40 \mathrm{~s} \text { (one-point) } \\
30-60 \mathrm{~s} \\
15-20 \mathrm{~min}\end{array}$ \\
\hline
\end{tabular}

TABLE II-Reproducibility of results in measuring $p H$, carbon dioxide pressure $\left(\mathrm{PCO}_{2}\right)$, and oxygen pressure $\left(\mathrm{Po}_{2}\right)$ with the three machines

\begin{tabular}{llcl}
\hline & ABL2 & Corning 175 & IL 613 \\
\hline $\mathrm{pH}$ & \pm 0.006 & \pm 0.005 & \pm 0.005 \\
$\mathrm{PCO}_{2}(\mathrm{kPa})$ & \pm 0.074 & \pm 0.073 & \pm 0.074 \\
$\mathrm{PO}_{2}(\mathrm{kPa})$ & $\pm 0.21^{*}$ & \pm 0.10 & \pm 0.10
\end{tabular}

*Includes aberrant result.

Conversion: SI to traditional units- $-\mathrm{PCO}_{2}$ and $\mathrm{Po}_{2}: 1 \mathrm{kPa} \approx 7.52 \mathrm{~mm} \mathrm{Hg}$.

TABLE III-Comparison of mean $( \pm S D)$ results obtained for $p H, \mathrm{PCO}_{2}$, and $\mathrm{PO}_{2}$ with the three automatic blood-gas analysers and Corning 165

\begin{tabular}{|c|c|c|c|c|c|}
\hline & $\begin{array}{c}\text { No of } \\
\text { paired } \\
\text { samples }\end{array}$ & $\begin{array}{l}\text { Value with } \\
\text { machine } \\
\text { studied }\end{array}$ & $\begin{array}{l}\text { Value with } \\
\text { Corning } 165\end{array}$ & $\begin{array}{c}\text { Correlation } \\
\text { coefficient } \\
(\mathrm{r})\end{array}$ & $\begin{array}{l}\text { Range } \\
\text { studied }\end{array}$ \\
\hline \multicolumn{6}{|c|}{$A B L 2$} \\
\hline \multirow[t]{2}{*}{$\begin{array}{l}\mathrm{pH} \\
\mathrm{PCO}_{2}(\mathrm{kPa}) \\
\mathrm{Po}_{2}(\mathrm{kPa})^{*} \\
\mathrm{Po}_{2}(\mathrm{kPa})\end{array}$} & $\begin{array}{l}17 \\
17 \\
17 \\
15\end{array}$ & $\begin{array}{c}7.402 \pm 0.057 \\
5.67 \pm 2.07 \\
9.58 \pm 6.51 \\
7.44 \pm 1.95\end{array}$ & $\begin{array}{c}7 \cdot 417 \pm 0.044 \\
6 \cdot 02 \pm 1 \cdot 39 \\
7 \cdot 69 \pm 2 \cdot 14 \\
7 \cdot 58 \pm 2 \cdot 26\end{array}$ & $\begin{array}{l}0.803 \\
0 \cdot 825 \\
0 \cdot 350 \\
0 \cdot 768\end{array}$ & $\begin{array}{c}7 \cdot 303-7 \cdot 512 \\
3 \cdot 38-9 \cdot 33 \\
4 \cdot 67-9 \cdot 78\end{array}$ \\
\hline & \multicolumn{5}{|c|}{ Corning 175} \\
\hline $\begin{array}{l}\mathrm{pH} \\
\mathrm{PcO}_{2}(\mathrm{kPa}) \\
\mathrm{PO}_{2}(\mathrm{kPa})\end{array}$ & $\begin{array}{l}23 \\
23 \\
23\end{array}$ & $\begin{array}{c}7.424 \pm 0.053 \\
5.39 \pm 1.07 \\
8.65 \pm 1.65\end{array}$ & $\begin{array}{c}7.429 \pm 0.050 \\
5 \cdot 19 \pm 0.92 \\
8 \cdot 30 \pm 1.61\end{array}$ & $\begin{array}{l}0.965 \\
0.851 \\
0.876\end{array}$ & $\begin{array}{c}7 \cdot 330-7 \cdot 526 \\
4 \cdot 12-6 \cdot 65 \\
6 \cdot 38-11 \cdot 04\end{array}$ \\
\hline \multicolumn{6}{|c|}{ IL 613} \\
\hline $\begin{array}{l}\mathrm{pH} \\
\mathrm{PCO}_{2}(\mathrm{kPa}) \\
\mathrm{Po}_{2}(\mathrm{kPa})\end{array}$ & $\begin{array}{l}19 \\
19 \\
19\end{array}$ & $\begin{array}{c}7.427 \pm 0.048 \\
5.04 \pm 1 \cdot 13 \\
9 \cdot 18 \pm 1.51\end{array}$ & $\begin{array}{c}7 \cdot 416 \pm 0.047 \\
5 \cdot 08 \pm 1 \cdot 17 \\
9 \cdot 18 \pm 1.92\end{array}$ & $\begin{array}{l}0.986 \\
0.905 \\
0.973\end{array}$ & $\begin{array}{c}7 \cdot 335-7 \cdot 666 \\
3 \cdot 64-7 \cdot 55 \\
5 \cdot 70-13 \cdot 45\end{array}$ \\
\hline
\end{tabular}

*Includes two aberrant results.

Conversion: SI to traditional units- $\mathrm{PcO}_{2}$ and $\mathrm{Po}_{2}: 1 \mathrm{kPa} \approx 7.52 \mathrm{~mm} \mathrm{Hg}$.

TABLE IV-Comparison of mean $\left( \pm S D\right.$ ) values of $p H, \mathrm{Po}_{2}$, and $\mathrm{PCO}_{2}$ obtained from simultaneous arterial and capillary blood samples in 40 patients

\begin{tabular}{|c|c|c|c|c|}
\hline & $\begin{array}{l}\text { Arterial } \\
\text { sample }\end{array}$ & $\begin{array}{l}\text { Capillary } \\
\text { sample }\end{array}$ & $\begin{array}{l}\text { Correlation } \\
\text { coefficient } \\
(\mathbf{r})\end{array}$ & $\begin{array}{c}\text { Range } \\
\text { studied }\end{array}$ \\
\hline $\begin{array}{l}\mathrm{pH} \\
\mathrm{PCO}_{2}(\mathrm{kPa}) \\
\mathrm{Po}_{2}(\mathrm{kPa})\end{array}$ & $\begin{array}{c}7 \cdot 426 \pm 0.048 \\
5.42 \pm 1 \cdot 35 \\
8.45 \pm 2.05\end{array}$ & $\begin{array}{c}7.431 \pm 0.046 \\
5.42 \pm 1.34 \\
7.52 \pm 1.41^{*}\end{array}$ & $\begin{array}{l}0 \cdot 644 \\
0 \cdot 890 \\
0 \cdot 835\end{array}$ & $\begin{array}{c}7 \cdot 339-7 \cdot 526 \\
3 \cdot 38-9 \cdot 33 \\
4 \cdot 33-11 \cdot 59\end{array}$ \\
\hline
\end{tabular}

*Capillary $\mathrm{Po}_{2}$ significantly lower: $\chi^{2}=27.916(\mathrm{DF}=3), \mathrm{P}<0.005$; paired $t$ test: $t=4.413, \mathrm{P}<0.001$

Conversion: SI to traditional units- $\mathrm{Pco}_{4}$ and $\mathrm{Po}_{2}: 1 \mathrm{kPa} \approx 7.52 \mathrm{~mm} \mathrm{Hg}$. of the ABL2 and Corning 175 but were more difficult on those of the IL 613, for which expert technical help was needed.

\section{Sampling}

The three sampling systems were different but basically easy to use, though with all three machines sample contamination with air bubbles occurred when they were used by inexperienced operators after a one-hour training period, and clotting of samples within the machine also occurred. A particularly good feature of the ABL2 was the automatic flush-out system that operated when the sample door was not closed. The need to fit connections to both ends of the capillary tubes on the Corning 175 made it more difficult to use for inexperienced operators and those who used it rarely.

\section{Results and printout}

Printout system-The Corning 175 had the best printout system, the results being printed automatically on a ticket, of which four copies were produced. With both the ABL2 (ticket printout) and the IL 613 (roll printout) only one copy of the results was produced, but a second copy could be obtained by pressing a button.

Aberrant results-Reproducibility was good on all three machines (table II), but aberrant results for $\mathrm{Po}_{2}$ were obtained on several occasions with the ABL2. This fault persisted despite changing the electrode. Both the Corning 175 and IL 613 had warning devices to indicate possible aberrant results, but the ABL2 did not.

Speed of results-see table I.

Barometric pressure adjustments-These were carried out automatically on the ABL2 and Corning 175 but the IL 613 required manual input.

\section{Faults and fault-finding}

$A B L 2-$ A flashing-light warning system of faults is incorporated in the ABL2, but we found it difficult sometimes to detect the type of fault, and on one occasion when the membrane of the $\mathrm{Po}_{2}$ electrode was faulty no fault was indicated. The code system used was unnecessarily obscure. Many simple faults that could have been corrected by a technician entailed visits from the service engineer or telephone consultations with the company. After shut-down-for example, to change the electrode membrane-the warm-up time to full activity of the machine was four hours (including the time for calibration).

Corning 175-A screen display system was used to indicate faults; most mechanical faults could be readily corrected by technicians, and the system operated particularly well for electrode faults. The warmup time after shut-down was two hours.

IL 613-This also used a screen display system, which permitted ready detection and correction of many faults by a technician, but the system was less comprehensive than that of the Corning 175 . The IL 613 had the shortest warm-up time after shut-down of 15 minutes.

\section{Other variables}

The Corning 175 was rather noisier in operation than the other machines. Standard pH solutions in $500 \mathrm{ml}$ bottles were provided with all three machines for calibration. We found this unsatisfactory because once the bottles were opened the $\mathrm{pH}$ of the solution in the bottle rose significantly by over 0.01 after five to seven days.

\section{BLOOD-GAS ANALYSES}

We carried out analyses of arterial blood with each machine and compared the results with those obtained with the Corning 165 controlled by regular use of tonometered blood. Table III summarises the results. With the Corning 175 we found no significant differences in $\mathrm{pH}, \mathrm{PCO}_{2}$, or $\mathrm{Po}_{2}$. In the measurements obtained with the ABL2 there was no significant difference in $\mathrm{pH}$ or $\mathrm{PCO}_{2}$. Two aberrant results were obtained for $\mathrm{Po}_{2}$ : both were due to membrane dysfunction, but the machine did not indicate that the results were abnormal. When all the $\mathrm{PO}_{2}$ measurements were considered the ABL2 gave a significantly higher mean value $(P<0.005)$ than the Corning 165 , but when the two aberrant results were ignored this difference was removed. The measurements of $\mathrm{Po}_{2}$ and $\mathrm{PCO}_{2}$ obtained with the 
IL 613 did not differ significantly from the results obtained with the Corning 165, but the mean $\mathrm{pH}$ values obtained from the same samples were significantly lower $(7 \cdot 416 \pm 0.047$ compared with $7 \cdot 427 \pm 0.048 ; \mathrm{P}<0.005$ ).

In 40 patients the results obtained from simultaneous arterial and capillary specimens were compared by analysis of variance and the paired $t$ test (table IV). There were no significant differences in $\mathrm{PCO}_{2}$ or $\mathrm{pH}$ but the $\mathrm{PO}_{2}$ values obtained from the capillary samples $(7.524 \pm 1.405 \mathrm{kPa}(56.6 \pm 10.6 \mathrm{~mm} \mathrm{Hg}))$ were significantly lower than those obtained from the arterial samples $(8.451 \pm 2.050 \mathrm{kPa}(63.5 \pm 15.4$ $\mathrm{mm} \mathrm{Hg})$ ), the results showing reasonably good correlation $(\mathrm{r}=0.835)$.

\section{Discussion}

Although only one model of each automatic blood-gas analyser was studied, the comparisons carried out were concerned with basic design and operation in relation to use in different clinical circumstances and with varying degrees of technical support. For clinical purposes all three machines performed satisfactorily in terms of blood-gas analysis and $\mathrm{pH}$ measurement.

None of the three machines studied could be regarded as fully automatic, and all required some maintenance by an experienced technician or operator. The IL 613 took up noticeably more technician time than the other two machines because of the daily manual calibration required and the more difficult and lengthy procedure for changing electrode membranes. Given the availability of an expert technician the most satisfactory faultfinding system was that of the Corning 175, since it permitted ready diagnosis and correction of many simple faults and electrode dysfunction. The fault-finding system of the IL 613 was also satisfactory, though less comprehensive than that of the Corning 175, but the system of the ABL2 was less efficient in terms of identifying faults because of the unnecessarily obscure code system used. We understand that a manual is available for interpreting this code but at extra cost. The printout of results seemed most satisfactory on the Corning 175 because copies were produced automatically, whereas with the ABL2 and IL 613 the operator had to press a button to obtain an additional copy, a procedure that may be neglected when results are required quickly.

In terms of reproducibility and accuracy of results the Corning 175 and IL 613 both performed well. The significant difference in mean $\mathrm{pH}$ values between the IL 613 and the control machine (Corning 165) may have been due to differences in the standard buffer solutions used, since the mean difference observed $(0 \cdot 11)$ was similar to the difference that could be expected within the guaranteed limits of accuracy of the buffer solutions provided $( \pm 0.005)$. The difference was in any case small and unlikely to be important clinically. The ABL2 gave satisfactory results for $\mathrm{PCO}_{2}$ and $\mathrm{pH}$. The two aberrant results for $\mathrm{PO}_{2}$ were due to membrane faults, and hence were not a basic fault of the machine itself. Both results would probably have been seen to be abnormal by an experienced clinician, but it is a disturbing feature of this machine that a clear fault in the electrode membrane was not indicated by the built-in faultfinding system. In general the reproducibilities of $\mathrm{Po}_{2}$ and $\mathrm{PCO}_{2}$ were well within the limits proposed by Minty and Nunn. ${ }^{5}$

Another factor that may affect the choice of an automatic blood-gas analyser is the site available for it. The noise level of the Corning 175 makes it unsuitable for direct siting in a ward or intensive care unit, and separate cubicle or room accommodation would be preferable. The other two machines were less noisy and could be sited directly in the ward or unit.

Our studies with inexperienced operators indicate that the machines cannot be used properly without adequate training, but the time required for this training is short (one to two hours).

While we have not considered all the factors that must be taken into account when purchasing a blood-gas analyser we conclude that none of the machines may truly be regarded as fully automatic and that for successful operation some degree of technical supervision is essential, as is proper training for all potential users.

We found that the daily maintenance checks of the Corning 175 and the ABL2 took up 20-30 minutes of technician time, and the weekly checks a further hour. The IL 613 was more expensive in technician time, requiring 45 minutes for the daily checks, which included manual two-point calibration, and one and a half hours for the weekly check, which included allowance for the occasional need to change tubing within the machine.

Minty and Nunn ${ }^{5}$ indicated the importance of quality control when using blood-gas analysers, and we agree that calibration for $\mathrm{PO}_{2}$ and $\mathrm{PCO}_{2}$ should be undertaken with tonometered blood as well as with the standard gases supplied, and that frozen standard serum should be used to monitor changes in $\mathrm{pH}$ electrode performance.

The comparison between arterial and capillary results for $\mathrm{pH}, \mathrm{PCO}_{2}$, and $\mathrm{Po}_{2}$ did not wholly bear out results reported previously. We found no significant difference for $\mathrm{PCO}_{2}$, confirming the results reported by Spiro and Dowdeswell. ${ }^{6}$ For arterial and capillary $\mathrm{Po}_{2}$ previous studies ${ }^{6} 7$ have reported no statistical differences when using the same capillary sampling technique, ${ }^{2}$ whereas in our series the $\mathrm{Po}_{2}$ was significantly lower in the capillary specimens, by a mean value of $0.93 \mathrm{kPa}(7.0$ $\mathrm{mm} \mathrm{Hg}$ ). The range of values of arterial $\mathrm{Po}_{2}$ studied by Spiro and Dowdeswell was $5 \cdot 32-10 \cdot 64 \mathrm{kPa}(40-80 \mathrm{~mm} \mathrm{Hg})$, similar to that in our study, but the results were obtained in only 11 subjects. In the 11 patients with hypoxaemia studied by MacIntyre $e t a l^{7}$ the mean value for $\mathrm{Po}_{2}$ (arterial sample) was higher $(10 \cdot 64 \pm 2.74 \mathrm{kPa}(80 \cdot 0 \pm 20 \cdot 6 \mathrm{~mm} \mathrm{Hg}))$ than that in the present study. The discrepancy between the present study and those reported previously might be attributable to the larger number of subjects with pronounced hypoxaemia, and it is noteworthy that the correlation coefficient obtained was 0.835 , which is similar to that of 0.79 reported by MacIntyre et al. ${ }^{7}$ The actual mean difference observed $(0.93 \mathrm{kPa}(7.0 \mathrm{~mm} \mathrm{Hg}))$ may not be significant for many clinical purposes but might be important when capillary values are used for research procedures.

Spiro and Dowdeswell ${ }^{6}$ reported a significant difference in $\mathrm{pH}$ values, although the difference was small and unlikely to be important clinically. In our study the agreement in $\mathrm{pH}$ values was good.

Requests for reprints should be addressed to Dr K Prowse.

\section{References}

${ }^{1}$ Godfrey, S, et al, British fournal of Diseases of the Chest, 1971, 65, 58.

2 Chalmers, C, Bird, B D, and Whitwam, J G, British fournal of Anaesthesia, 1974, 46, 253.

${ }^{3}$ Else, W, Nature, 1972, 239, 474.

${ }^{4}$ Silvey, S D, Statistical Inference, p 108. London, Chapman and Hall, 1970.

5 Minty, B D, and Nunn, J F, Annals of Clinical Biochemistry, 1977, 14, 245.

${ }^{6}$ Spiro, S G, and Dowdeswell, I R G, British Fournal of Diseases of the Chest, 1976, 70, 263.

${ }^{7}$ MacIntyre, J, Norman, J W, and Smith, G, British Medical fournal, $1968,3,640$.

(Accepted 31 October 1978)

ONE HUNDRED YEARS AGO Two new coffee-taverns were opened in London on Saturday, March 15th; one at the Cross Keys, 42, Hampstead Road, at which short introductory addresses were given by $\mathrm{Mr}$ Forsyth, MP, Mr Pope, and Mr Ernest Hart [Editor, BMF]; and another at 79 , Wigmore Street, Manchester Square, at which also there was an opening ceremony, and short speeches explaining the objects and prospects of the place were given by $\mathrm{Mr}$ Shaw Lefevre, MP, and Mr Hart. The latter place has the special features of being designed largely for the use of shopwomen who are employed in the neighbourhood, and is under the superintendence of Miss Miller, who has borne the expense. We are glad to see that the Liverpool cocoa-houses continue to flourish exceedingly and to multiply in number. (British Medical fournal, 1879.) 